\title{
FEATURES OF MELTING, STRUCTURE AND PROPERTIES OF Ni-Mn-Cu SYSTEM NICKEL ALLOYS
}

\author{
V.F. KHORUNOV and P.N. LOTOTSKY \\ E.O. Paton Electric Welding Institute, NASU \\ 11 Bozhenko Str., 03680, Kiev, Ukraine. E-mail: office@paton.kiev.ua
}

\begin{abstract}
Influence of nickel alloy composition and method of melting on their structure and properties were studies. Melting was performed in argon and under a layer of flux. It is established that argon-arc melting of nickel alloys with high manganese content allows producing ingots of a more stable composition than in submerged-arc melting. It is noted that alloys of the considered system are prone to porosity. Increase of pouring temperature promotes reduction of porosity in ingots. Structure of ingots with different manganese content in as-cast condition, after annealing and rolling was studied. It was shown that at manganese content in the alloys of up to 25 wt.\%, it is possible to produce ingots of a higher strength and ductility, which lend themselves easily to forming. After rolling the alloys have the structure of fine-grained solid solution. Strength of such a metal reaches $900-950 \mathrm{MPa}$ at relative elongation of about $40 \%$. At greater manganese content the alloys become brittle as a result of formation of intermetallic phases in them. 8 Ref., 3 Tables, 7 Figures.
\end{abstract}

Key words: Ni-Mn-Cu system alloys, submergedarc and inert-gas arc melting, structure, mechanical properties of alloys, brazing, braze alloy

It is known that Fe-based structural materials usually have the structure of a solid solution, while braze alloys in their majority are eutectics, often having brittle phases in their composition. This contradiction is eliminated due to brazed joint design, brazing modes or some special techniques. Therefore, development of braze alloys based on solid solutions has been an urgent task for a number of years.

$\mathrm{Ni}-\mathrm{Mn}-\mathrm{Cu}$ system alloys have been quite well studied in many works [1-4]. Analysis of phase composition of this system alloys shows [1] that it has broad areas of alloys with solid solution structure with acceptable melting temperature for brazing corrosion-resistant steels. These are, mainly, Cu-based alloys. This system is the base for such well-known braze alloys as VPR-2, VPR-4, PM38ML, PM-17, P65, etc. [5, 6]. Nickel alloys of this system are not in such a good situation. Among widely accepted braze alloys we can mention US braze alloy $\mathrm{BNi}-8$, but it is eutectic with 7 wt.\% Si. In works [7, 8] alloys of this system were studied in the field of concentrations, wt.\%: $7-27 \mathrm{Mn}, 7-27 \mathrm{Cu}, 1-10 \mathrm{Si}$, Ni being the rest, in order to determine the possibility of producing eutectic alloys with a lower content of silicon. The most interesting results were obtained when studying alloys of $\mathrm{Ni}-24 \mathrm{Mn}-\mathrm{Cu}-\mathrm{Si}$ system.

(c) V.F. KHORUNOV and P.N. LOTOTSKY, 2014
Nonetheless, development of a braze alloy with solid solution structure is an attractive prospect, but it is very difficult to implement. The purpose of this work was to study the structure and properties of nickel alloys of $\mathrm{Ni}-\mathrm{Mn}-\mathrm{Cu}$ system, depending on composition and melting technology.

Analysis of the constructed respective constitutional diagram (Figure 1) shows that the regions of $\mathrm{NiMn}$ and $\mathrm{Ni}_{3} \mathrm{Mn}$ intermetallic phases have an extension in the three-component system up to a certain copper content. We have studied the structure and properties of the alloys, located in the near-boundary region (see Figure 1; Table 1). As is seen from the Table and presented diagrams, moving along the abscissa of 19 wt.\% $\mathrm{Cu}$, we must go over from alloys with solid solution structure to a structure with intermetallic compounds.

Melts were performed under a layer of cryolite. The alloy was poured into a cast iron mould, and then the possibility of ingot rolling was tried out and the microstructure was studied.

Microstructure of ingot 8 with low manganese content (20 wt.\%) is single-phase in the cast and annealed conditions (Figure 2, $a, b$ ). Intercrystalline boundaries are clean. With manganese increase up to 25 wt.\% (ingot 9), an eutectic component precipitates in interdendritic regions in the ingot center, and the structure becomes twophase (Figure 2,c). However, annealing at $950{ }^{\circ} \mathrm{C}$ restores the single-phase structure through the entire ingot volume (Figure $2, d$ ). The alloys can be rolled down to a rod with $14 \mathrm{~mm}$ side. 


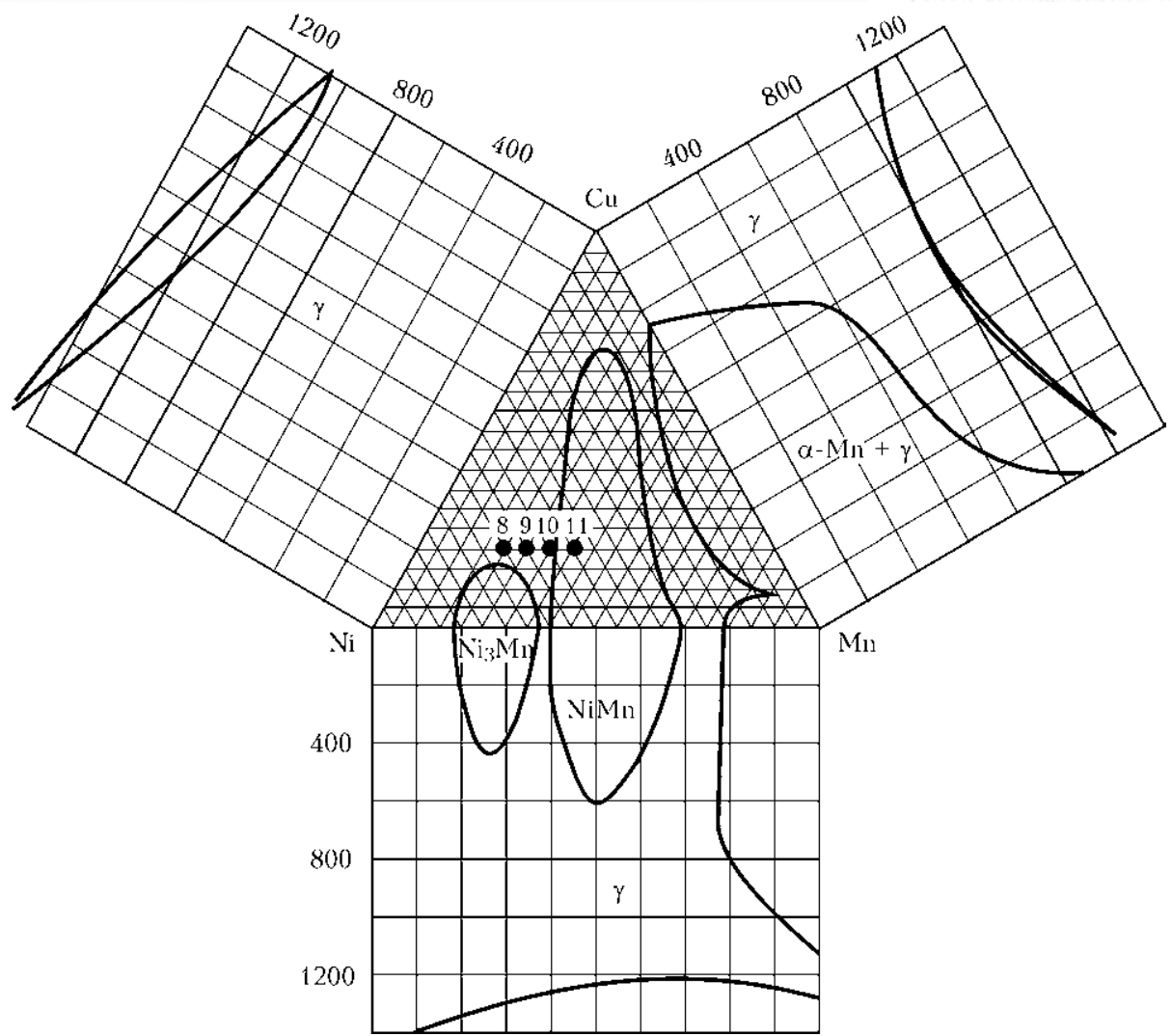

Figure 1. Phase areas in alloys of $\mathrm{Ni}-\mathrm{Mn}-\mathrm{Cu}$ system, compared to phase areas in binary systems [1]: 8-11 - number of ingot acc. to Table 1

Table 1. Composition and structure of the studied alloys

\begin{tabular}{|c|c|c|c|c|c|c|c|c|}
\hline \multirow{2}{*}{ Ingot number } & \multicolumn{5}{|c|}{ Composition, wt.\% } & \multirow{2}{*}{$\begin{array}{c}\text { Ingot weight, } \\
\text { kg }\end{array}$} & \multirow{2}{*}{$\begin{array}{l}\text { Second phase } \\
\text { quantity, \% }\end{array}$} & \multirow{2}{*}{ Porosity, \% } \\
\hline & $\mathrm{Ni}$ & Mn & $\mathrm{Cu}$ & $\mathrm{Si}$ & $\mathrm{Ce}$ & & & \\
\hline 8 & 60 & 20 & 19 & 0.9 & 0.2 & 5 & No & 18 \\
\hline 9 & 55 & 25 & 19 & 0.9 & 0.2 & 5 & 1.55 & 10 \\
\hline 10 & 50 & 30 & 19 & 0.9 & 0.2 & 5 & 7.3 & 9 \\
\hline 11 & 45 & 35 & 19 & 0.9 & 0.2 & 5 & 10.1 & 1 \\
\hline
\end{tabular}

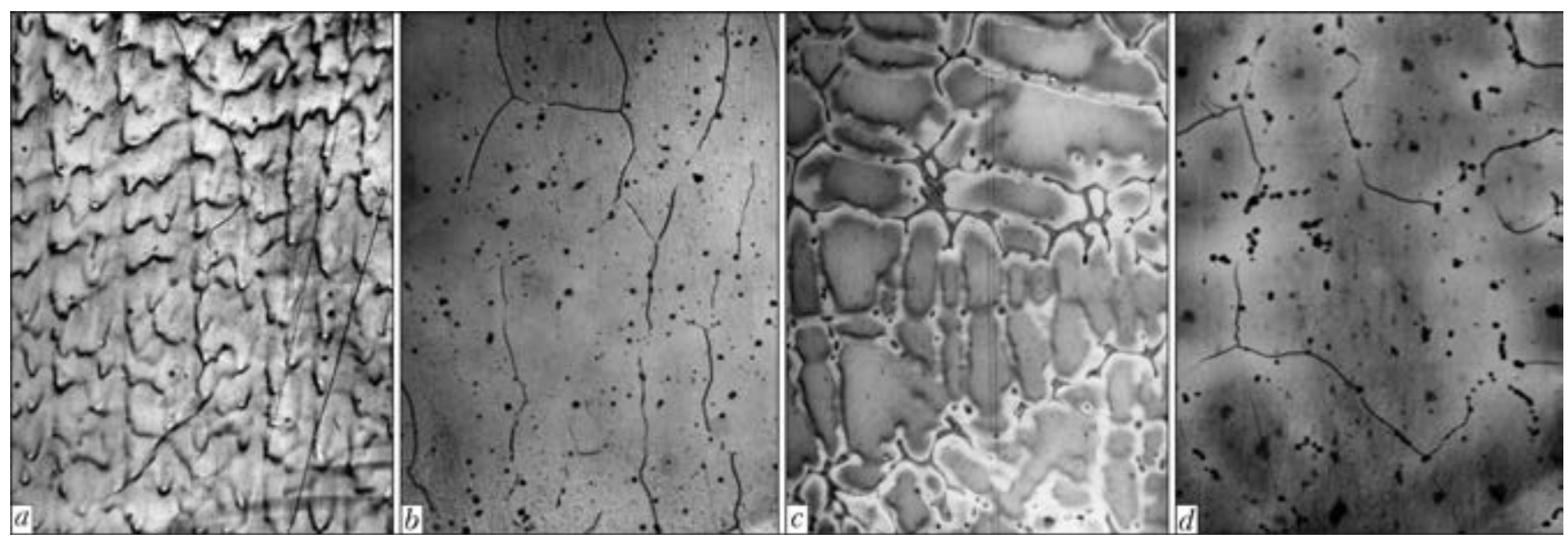

Figure 2. Microstructure $(\times 200)$ of ingots of $\mathrm{Cu}-\mathrm{Mn}-\mathrm{Ni}$ system alloys with $20 \mathrm{wt} . \% \mathrm{Mn}(a, b)$ and 25 wt.\% Mn $(c, d)$ in as-cast condition $(a, c)$ and after annealing at $950{ }^{\circ} \mathrm{C}(b, d)$ 


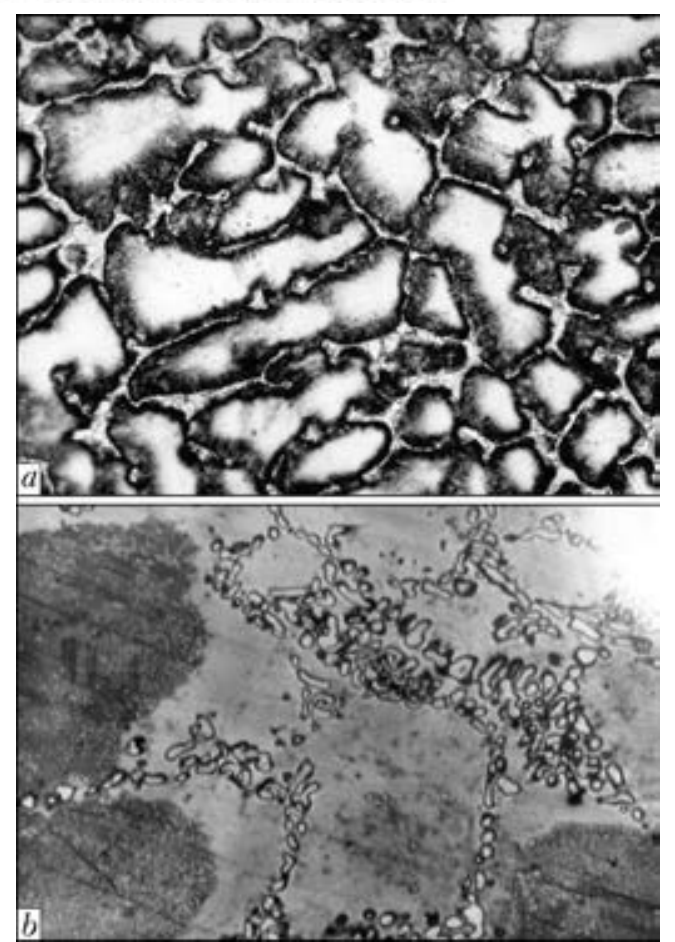

Figure 3. Microstructure $(\times 200)$ of ingots of $\mathrm{Cu}-\mathrm{Mn}-\mathrm{Ni}$ system alloys with $35 \mathrm{wt} . \% \mathrm{Mn}$ in as-cast condition $(a)$ and after annealing at $950{ }^{\circ} \mathrm{C}(b)$

At further increase of manganese content (30 wt.\% in ingot 10), the quantity of second phase is increased, and at $35 \mathrm{wt} \% \mathrm{Mn}$ (ingot 11), it fills the entire space between the dendrites (Figure 3,a). Analysis of ternary $\mathrm{Ni}-\mathrm{Mn}-\mathrm{Cu}$ diagram [2] shows that at such a component ratio matrix embrittlement and strengthening results from ordering (or precipitation of NiMn type phase).

In the studied alloys the composition of intermetallic phase, precipitating along the crystallite boundaries, differs from precipitates inside the matrix mainly by increased silicon content, which is one of the elements stabilizing the ordered matrix phase. Therefore, silicon presence should facilitate alloy solidification in interdendritic areas of the ingot in the form of intermetallic phase. In this case, annealed alloys are also two-phase (Figure 3,b), have an increased hardness and brittleness, and fail along crystallite boundaries at treatment.
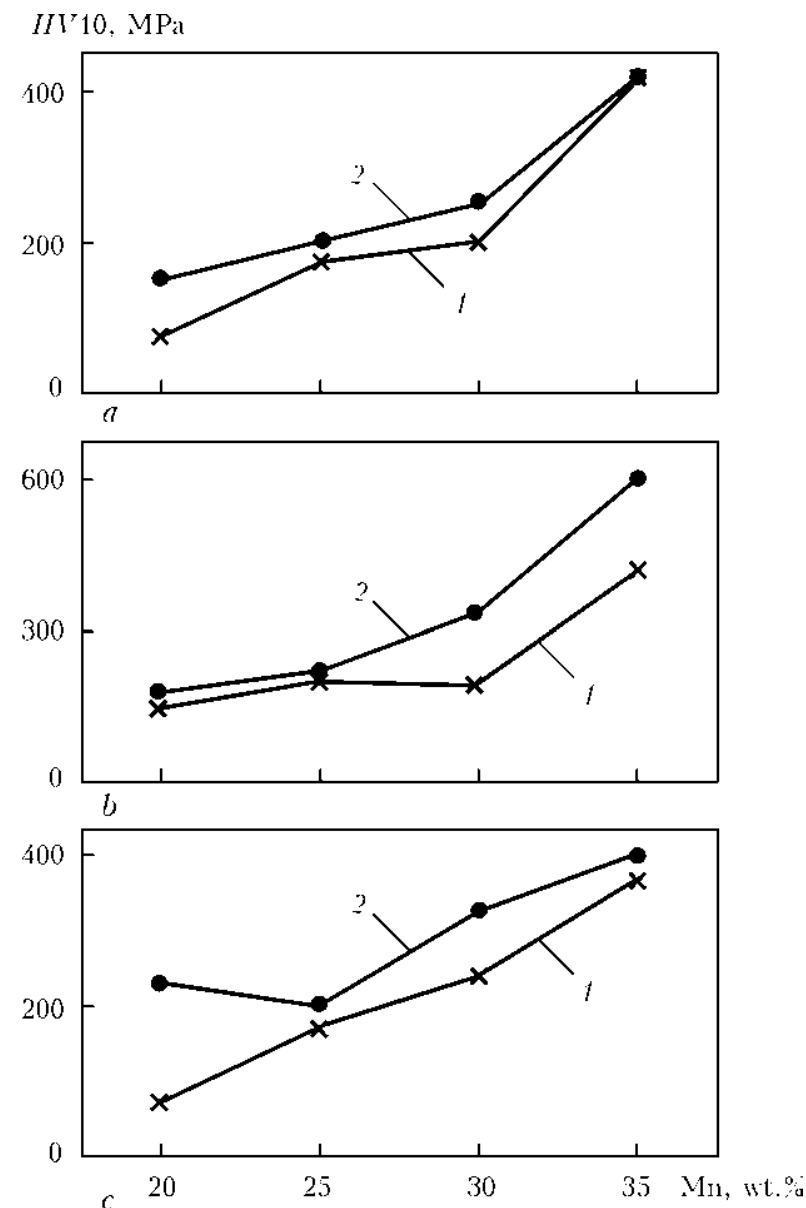

Figure 4. Dependence of microhardness of dendritic (1) and interdendritic (2) areas for ingots 8-11 on manganese content: $a$ - ingot edges; $b$ - intermediate part; $c$ - ingot central part

Curves reflecting the dependence of microhardness of dendritic and interdendritic areas of cast metal on manganese content, show that at addition of 35 wt.\% Mn to the alloy (ingot 11) hardnesses of the matrix and intermetallic interlayers are close or coincide that allows once more assuming the ordered matrix condition (Figure 4). The curves have a characteristic plateau of dendrite hardness in the range of $25-30 \% \mathrm{Mn}$ (except for the curve describing the ingot central parts).

Filler with a high content of manganese and appearance of strengthening phases should increase the angle of inclination of the curve that is observed on some graphs (see Figure 4). An

Table 2. Composition and pouring temperature of the alloys

\begin{tabular}{|c|c|c|c|c|c|c|c|c|c|}
\hline \multirow{2}{*}{ Ingot number } & \multicolumn{7}{|c|}{ Charge composition, wt.\% } & \multirow{2}{*}{$\begin{array}{l}\text { Ingot mass, } \\
\qquad \mathrm{kg}\end{array}$} & \multirow{2}{*}{$\begin{array}{c}\text { Pouring } \\
\text { temperature, } \\
{ }^{\circ} \mathrm{C}\end{array}$} \\
\hline & $\mathrm{Ni}$ & $\mathrm{Mn}$ & $\mathrm{Cu}$ & $\mathrm{Si}$ & $\mathrm{Cr}$ & Mo & $\mathrm{Ce}$ & & \\
\hline 12 & 55 & 25 & 19 & 0.8 & - & - & - & 5 & 1300 \\
\hline 13 & 52 & 25 & 19 & 0.8 & 2 & 0.75 & 0.3 & 22 & 1200 \\
\hline 14 & 52 & 25 & 19 & 0.8 & 2 & 0.75 & 0.3 & 22 & 1250 \\
\hline 15 & 52 & 25 & 19 & 0.8 & 2 & 0.75 & 0.3 & 22 & 1300 \\
\hline
\end{tabular}



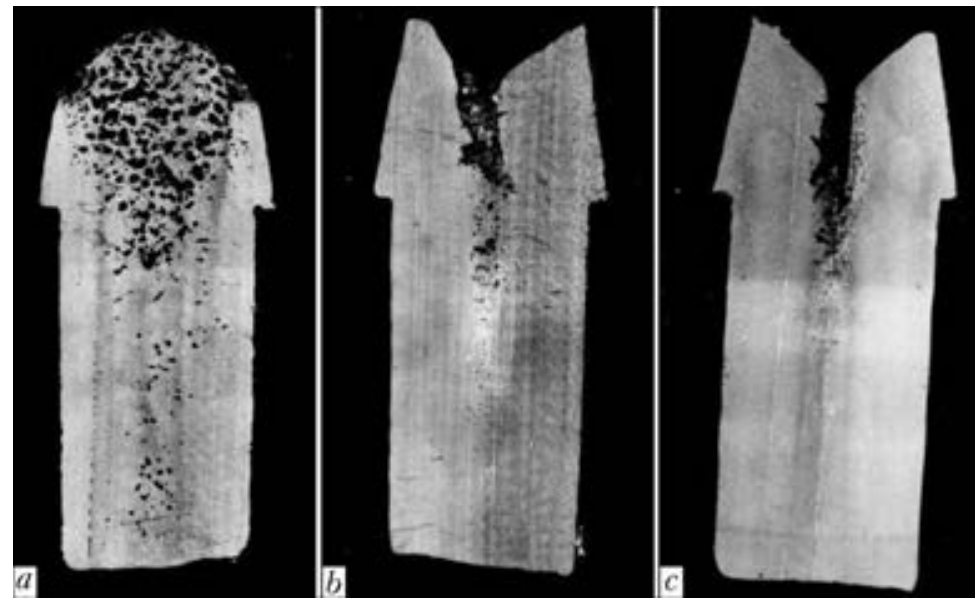

Figure 5. Longitudinal cut of ingots of $\mathrm{Ni}-\mathrm{Mn}-\mathrm{Cu}-\mathrm{Si}-\mathrm{Cr}-\mathrm{Mo}-\mathrm{Ce}$ system alloy with different pouring temperature: $a-$ $1200 ; b-1250, d-1300{ }^{\circ} \mathrm{C}$

abrupt change of the trend of the curve at manganese content of $30 \mathrm{wt} . \%$ and higher, certainly is indicative of intensive development of the process of strengthening due to ordering.

Mechanical characteristics of the alloys are also in accordance with hardness values. Ingots with low manganese content are readily formable and ductile, whereas with manganese increase in the alloys their ductility decreases and treatment becomes more complicated. Alloys with 35 wt.\% Mn fail at machining and electrical-discharge treatment.

A considerable problem in melting high-manganese alloys is porosity development in the in-
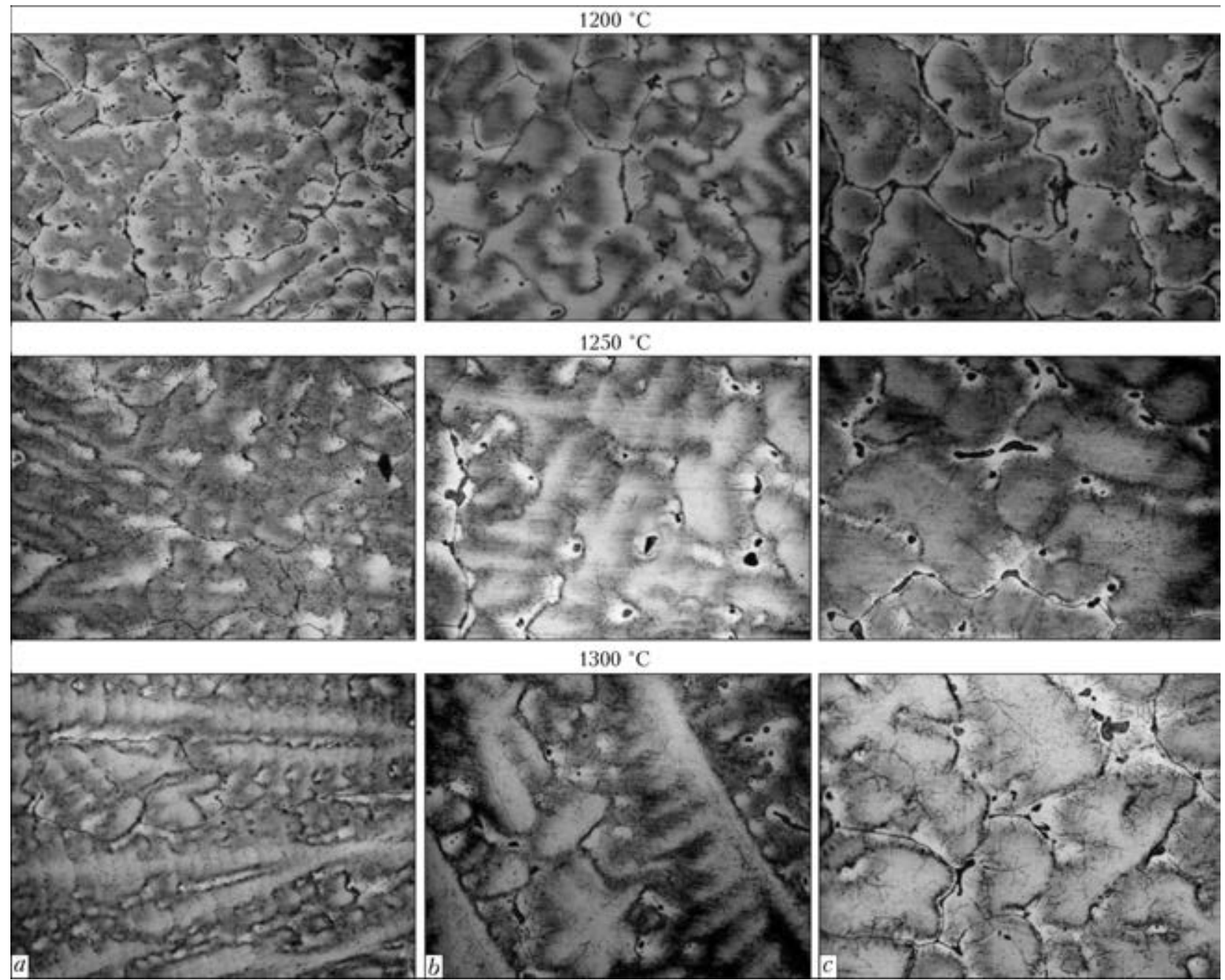

Figure 6. Microstructure $(\times 200)$ of $\mathrm{Ni}-\mathrm{Mn}-\mathrm{Cu}-\mathrm{Si}-\mathrm{Cr}-\mathrm{Mo}$ system alloys poured at different temperature: $a-$ ingot edge; $b$ - intermediate part; $c$ - ingot central part 
SCIENTIFIC AND TECHNICAL

Table 3. Composition and mechanical characteristics of test studied alloys

\begin{tabular}{|c|c|c|c|c|c|c|c|c|c|c|c|c|c|}
\hline \multirow{2}{*}{$\begin{array}{l}\text { Ingot } \\
\text { number }\end{array}$} & \multicolumn{8}{|c|}{ Composition, wt. $\%$} & \multicolumn{4}{|c|}{ Mechanical characteristics } & \multirow{2}{*}{ Shielding atmosphere } \\
\hline & $\mathrm{Ni}$ & $\mathrm{Mn}$ & $\mathrm{Cu}$ & $\mathrm{Si}$ & $\mathrm{Cr}$ & Mo & $\mathrm{Ce}$ & $\mathrm{Al}$ & $\begin{array}{c}\sigma_{\mathrm{y}}, \\
\mathrm{MPa}\end{array}$ & $\begin{array}{c}\sigma_{\mathrm{t}} \\
\mathrm{MPa}\end{array}$ & $\delta, \%$ & $\psi, \%$ & \\
\hline \multirow[t]{2}{*}{5} & \multirow[t]{2}{*}{54} & 25 & 20 & 1 & \multirow[t]{2}{*}{-} & \multirow[t]{2}{*}{-} & \multirow[t]{2}{*}{-} & 0.8 & \multirow[t]{2}{*}{615} & \multirow[t]{2}{*}{970} & \multirow[t]{2}{*}{39} & \multirow[t]{2}{*}{54} & \multirow[t]{6}{*}{ «Cryolite» flux } \\
\hline & & 23.9 & 20 & 0.9 & & & & 0.22 & & & & & \\
\hline \multirow[t]{2}{*}{6} & \multirow[t]{2}{*}{50} & 30 & 19 & \multirow[t]{2}{*}{-} & \multirow[t]{2}{*}{-} & \multirow[t]{2}{*}{-} & \multirow[t]{2}{*}{0.1} & 0.8 & \multirow[t]{2}{*}{453} & \multirow[t]{2}{*}{760} & \multirow[t]{2}{*}{40} & \multirow[t]{2}{*}{53} & \\
\hline & & 23.7 & 20.7 & & & & & 0.36 & & & & & \\
\hline \multirow[t]{2}{*}{7} & \multirow[t]{2}{*}{53} & 25 & 19 & 1 & 2 & 0.75 & \multirow[t]{2}{*}{0.3} & - & \multirow[t]{2}{*}{580} & \multirow[t]{2}{*}{900} & \multirow[t]{2}{*}{41} & \multirow[t]{2}{*}{50} & \\
\hline & & 22.6 & 19.8 & 0.94 & 2.8 & ND & & & & & & & \\
\hline \multirow[t]{2}{*}{2} & 54.8 & 23.8 & 20.5 & 0.87 & \multirow[t]{2}{*}{-} & \multirow[t]{2}{*}{-} & \multirow[t]{2}{*}{-} & - & \multirow[t]{2}{*}{-} & - & - & - & Argon \\
\hline & 52.5 & 22.8 & 19.9 & 0.96 & & & & & & & & & (after degassing) \\
\hline 3 & 54.8 & 23.8 & 20.5 & 0.87 & - & 1.5 & - & - & 568 & 950 & 36 & 48 & \\
\hline & 52.5 & & 21.6 & 0.71 & & 1.44 & & & & & & & \\
\hline
\end{tabular}

gots, which is manifested both in submerged-arc and in argon-arc melting. The regularity of its appearance has not been established, as it is very expensive to melt out a large number of alloys for statistical assessment. Therefore, special experiments were performed to determine the influence of alloy melting temperature on porosity formation (Table 2). Melting was conducted with ANM-10 flux, the application of which is simpler than that of cryolite.

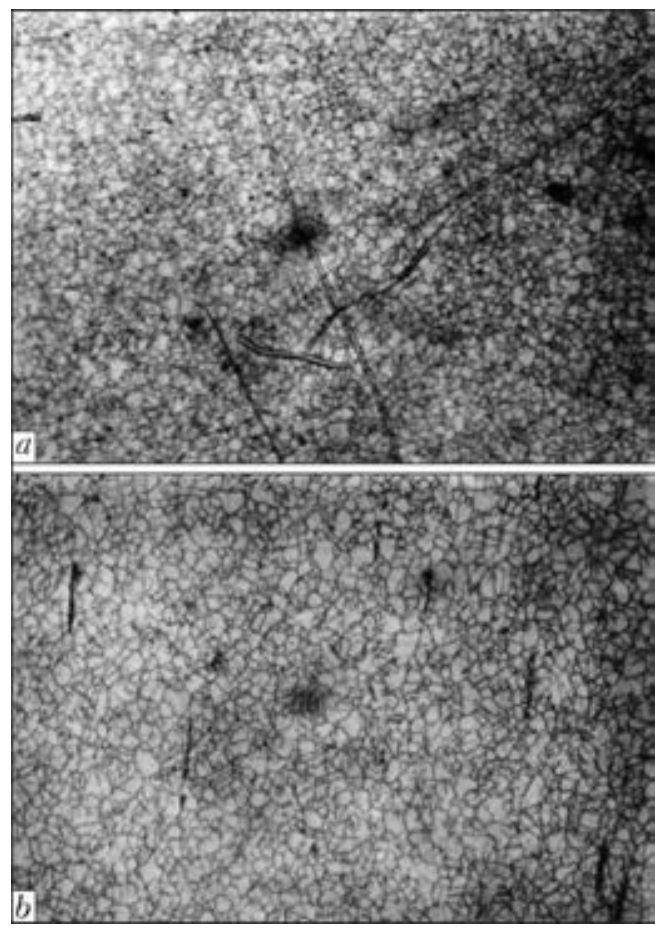

Figure 7. Microstructure $(\times 400)$ of $\mathrm{Ni}-24.3 \mathrm{Mn}-22.5 \mathrm{Cu}-$ $0.64 \mathrm{Si}$ alloy rolled into a rod with $14 \mathrm{~mm}$ side: $a-$ in-plane structure normal to the rolling direction; $b-$ rod structure along the rolling direction
Liquid metal was poured into cast iron moulds. Produced ingots were cut along and ground over the cut surface. It is readily seen (Figure 5) that ingot porosity is reduced with increase of pouring temperature; however, the size of shrinkage cavity is increased. The same regularity was established also at microstructural investigations in different parts of the ingots. Naturally, this is particularly clearly seen, if we compare the structures in the ingot central part (Figure 6), as this is related to the conditions of heat removal from the liquid metal and direction of crystallite growth, respectively.

Obtained results were the basis for conducting further experiments. A number of alloys of the above-considered quaternary system (and also with some additional alloying) with less than 25 wt.\% Mn content were melted by submergedarc and argon-arc process. Obtained ingots were rolled into a square with 25 or $14 \mathrm{~mm}$ side, from which specimens were cut out for metallographic studies and samples were taken for chemical analysis. Experimental results are given in $\mathrm{Ta}-$ ble 3 .

From the tabulated data it follows that losses of manganese - an element with a high vapour pressure - are not higher than 1 wt.\% in argonarc melting with preliminary degassing, whereas in submerged-arc melting a large scatter is observed, which is higher than 5 wt.\% in some cases.

Filler of small amounts of aluminium, chromium and molybdenum does not essentially affect the mechanical properties of melted metal, namely ductile high-strength alloys were produced. For most of the melts, rupture strength of the alloys was above $90 \mathrm{MPa}$, while relative 
elongation was about $40 \%$. Alloy structure is fine-grained solid solution, rolling texture is not clearly manifested. However, grains across the rolling direction are noticeably smaller than those along the rolling direction.

The considered alloys have an acceptable melting range, and they can become widely accepted in industry for brazing steels of various classes, hard alloys and other materials.

\section{Conclusions}

1. Melting in argon atmosphere (with preliminary degassing) of $\mathrm{Ni}-\mathrm{Mn}-\mathrm{Cu}$ system alloys with high manganese content allows producing ingots of a more stable composition. However, the difference in quality is not so radical as to override the high cost of this process, compared to submerged-arc melting.

2. Nickel alloys with high manganese content are prone to porosity. One of the methods to solve this problem is to increase pouring temperature.

3. At up to 25 wt.\% Mn ductile, high-strength alloys are produced, which are readily formable. At higher manganese content the alloys become harder and more brittle, and do not lend themselves to forming.
4. Braze alloys based on the considered alloys will become widely accepted for brazing steels of different classes, hard alloy and other materials, also in dissimilar combinations.

1. Salli, A. (1959) Manganese. Moscow: Metallurgizdat.

2. Bochvar, N.R., Guzej, L.S., Lysova, E.V. et al. (1979) Binary and multicomponent systems on copper base. Moscow: Nauka.

3. Chjan-Bao-Chan (1958) Examination of ternary alloys $\mathrm{Cu}-\mathrm{Mn}-\mathrm{Ni}$. Izvestiya Vuzov. Tsvet. Metallurgiya, 5, 107-115.

4. Bazhenov, V.E. (2013) Study of crystallization processes of ternary alloys for the purpose of evaluation of their susceptibility to nonequilibrium crystallization: Syn. of Thesis for Cand. of Techn. Sci. Degree.

5. (2003) Reference book on soldering. Ed. by I.E. Petrunin. 3rd ed. Moscow: Mashinostroenie.

6. Lashko, S.V., Lashko, N.F. (1988) Brazing of metals. Moscow: Mashinostroenie.

7. Khorunov, V.F. (2008) Principles of brazing thinwalled high-alloy steel structures. Kiev: Naukova Dumka.

8. Khorunov, V.F., Doroshenko, L.K., Vasiliev, V.G. (1988) Diagram of meltability and structure of alloys of nickel-manganese-copper-silicon system. Avtomatich. Svarka, 9, 32-36.

Received 14.01.2014 